\title{
PEMBELAJARAN PKn BERBASIS MULTIKULURALISME PERSPEKTIF PSIKOLOGI SOSIAL ISLAM
}

\author{
Baidi \\ FITK Institut Agama Islam Negeri (IAIN) Surakarta \\ Email: baidi@yahoo.com
}

\begin{abstract}
This article describes the learning of Civics comprising three relations namely the relation between Civics and Islamic social psychology, Civics and multiculturalism, and Civics, Islamic social psychology, and multiculturalism. The method used is descriptive qualitative to describe the relationship among the existing facts employing multiple embedded case study design. The findings indicate that the diversity of the community is a necessity. The diversity can lead to vulnerable conflict. Some conflicts in various regions assert the importance of maintaining harmony in diversity. Avoiding conflicts requires people's understanding on multiculturalism in a diverse society. It can be learned through multicultural based Civics with the perspective of Islamic social psychology. It is expected to form smart and good citizenship as a manifestation of multiculturalism in Indonesian context.
\end{abstract}

Artikel ini menjelaskan pembelajaran Pendidikan Kewarganegaraan (PKn) yang meliputi tiga relasi yaitu antara PKn dengan psikologi sosial Islam, antara PKn dan multikulturalisme, dan antara PKn, multikulturalisme dan psikologi sosial Islam. Metode yang digunakan yaitu deskriptif kualitatif untuk menggambarkan hubungan fakta-fakta yang ada dengan desain studi kasus majemuk. Hasil temuan menunjukkan bahwa keragaman masyarakat merupakan suatu keniscayaan. Keragaman bisa menimbulkan kerawanan konflik. Beberapa konflik yang terjadi di berbagai daerah menyadarkan betapa pentingnya menjaga kerukunan dalam keragaman. Untuk mencegah terjadinya konflik diperlukan pemahaman warga masyarakat terhadap multikulturalisme dalam masyarakat yang beragam. Pemahaman multikulturalisme dapat diajarkan melalui pembelajaran PKn 
berbasis multikulturalisme dalam perspektif psikologi posial Islam. Diharapkan terbentuk sosok warga negara yang cakap dan berkarakter sebagai perwujudan multikulturalisme dalam konteks Indonesia.

Keywords: PKn, multiculturalism, social psychology

\section{Pendahuluan}

Reformasi tahun 1998 keragaman kultur di Indonesia mendapatkan ujian yang serius, yang ditandai berbagai konflik kekerasan yang bersifat komunal, seperti konflik Sambas, Ambon, Poso dan Surakarta. Konflik sosial yang berbau SARA ini tidak bisa dianggap remeh, karena kemungkinan akan menyulut konflik di daerah lainnya. Realitas empiris ini juga menunjukkan bahwa masih ada persoalan mendasar yang belum terselesaikan (Yaqin, 2005: 45). Pengalaman konflik beberapa waktu yang lalu telah mengantarkan kepada penderitaan dan kerugian yang ditimbulnya, menyebabkan upaya-upaya yang bisa dilakukan untuk mencegah dan memperbaiki kondisi sosial yang lebih harmoni dan kedamaian.

Gagasan utama dalam penelitian ini adalah multikulturalisme, psikologi sosial Islam yang implementasinya dalam pembelajaran PKn, Tujuan pembelajaran PKn yang berbasis multikulturalisme adalah untuk membentuk warga negara yang cerdas dan baik dalam konteks Indonesia. Bangsa Indonesia merupakan masyarakat majemuk budaya, agama, etnis, bahasa dan lainnya. Walau berbeda tetap satu, sebagaimana semboyan Bhinneka Tunggal Ika. Pembelajaran PKn secara psikologis adalah terjadinya perubahan tingkah laku secara permanen pada diri peserta didik sesuai tujuan yang akan dicapai yaitu smart and good citizenship.Tentu perilaku yang dimaksud adalah perilaku sosial dalam kehidupan bersama.Sedang perspektif Islam lebih menekankan pada kaidah al Quran dan Sunnah sebagai pedoman bertingkah laku sosial. Secara konseptual titik temu dari ketiganya adalah mengkaji pembelajaran PKn dalam konteks masyarakat multikulturalisme yang dapat menimbulkan perubahan tingkah laku peserta didik sesuai dengan al Quran dan hadits yaitu membentuk warga negara yang baik dan cerdas.

Artikel ini menjelaskan pembelajaran PKn berbasis multikultural dalam perspektif psikologi sosial Islam yang meliputi relasi antara: 1) PKn denganpsikologi sosial Islam, 2) PKn dengan multikulturalisme, 3) psikologi sosial Islam dengan multikulturalisme, 4) PKn dengan multikulturalisme dan psikologi sosial Islam. Disamping itu juga dijelaskan bahwa smart and 
good citizenship merupakan perwujudan dari humanisme Islam dalam konteks Indonesia.

\section{Metode Penelitian}

Metode penelitian yang digunakan dalam penelitian ini adalah metode penelitian kualitatif deskriptif dengan desain embaded case study. Subjek penelitian terdiri Guru PKn dan siswa kelas VIII. Sedangkan informan penelitian terdiri dari Kepala Sekolah, anggota KKG PKn. Tehnik pengumpulan data dengan wawancara, observasi dan dokumentasi. Keabsahan data dengan tehnik trianggulasi metode dan sumber. Tehnik analisis data menggunakan analisis model interaktif (interactive model analysis) yang terdiri dari pengumpulan data, reduksi data, penyajian data, dan verifikasi.

\section{Pembahasan}

Pendidikan kewarganegaraan (PKn) menjadi pintu masuk untuk memberikan muatan dalam pembelajaran yang diharapkan bisa menyisir kekurangan selama ini, yang memberikan dampak negatif terhadap bangunan character building sumber daya manusia Indonesia.

Secara konseptual PKn memiliki tiga domain, yakni: domain akademis, kurikuler, dan sosio kultural. Ketiga domain ini berkaitan secara struktural dan fungsional, dan diikat dalam prinsip civic virtue dan civic culture. Sifat multidimensional dari PKn membuat bidang studi ini berelasi dengan pendidikan politik, pendidikan nilai dan moral, pendidikan kebangsaan, pendidikan kemasyarakatan, pendidikan hukum dan hak asasi manusia, dan pendidikan demokrasi (Winataputra, 2012: 14). PKn memberikan dasardasar dalam kehidupan sosial peserta didik agar mempunyai karakter yang mendukung dalam kehidupan sosial, bisa membawakan diri dalam lingkungan sosial apapun kondisinya, mempunyai pemahaman dan sikap yang baik dalam menyelesaikan setiap perbedaan yang ada, mampu memecahkan masalah.

\section{Relasi PKn dan Psikologi Sosial Islam}

Membicarakan manusia tidak lepas dari upaya untuk mengungkap hakikat manusia dan aspek kejiwaannya yang berhubungan dengan orang lain. Manusia secara struktur mempunyai aspek jasmani dan rohani, yang di dalamnya perludikaji hakikat keberadaannya. Aspek rohani yang berhubungan dengan unsur kejiwaan manusia, sehingga kajian tentang manusia mengantarkan pada pembahasan dalam psikologi. Secara umum, psikologi adalah kajian 
tentang realitas kehidupan manusia dari aspek kejiwaan dan potensi-potensi di tengah alam dan realitas sosial yang ada.

Psikologi modern mengembangkan kajian sebagai ilmu yang mempelajari perilaku manusia dengan asumsi bahwa perilaku merupakan ungkapan dan cerminan dari kondisi, proses, dan fungsi-fungsi kejiwaan (Bastaman, 2005: 34). Ilmu jiwa meliputi segala pemikiran, pengetahuan, tanggapan, tetapi juga segala khayalan dan spekulasi mengenai jiwa itu. Sementara itu, psikologi meliputi ilmu pengetahuan mengenai jiwa yang diperoleh secara sistematis dengan metode-metode ilmiah yang memenuhi syarat-syaratnya seperti yang dimufakati sarjana-sarjana psikologi pada zaman sekarang ini. Istilah ilmu jiwa menunjuk kepada ilmu jiwa pada umumnya, sedangkan psikologi menunjukkan ilmu jiwa yang ilmiah menurut norma-norma ilmiah modern (Gerungan, 1987: 1).

Bertolak dari pengertian psikologi sebagai ilmu yang menelaah perilaku manusia, para ahli psikologi umumnya berpandangan bahwa kondisi ragawi, kualitas kejiwaan dan situasi lingkungan merupakan penentu-penentu utama perilaku dan corak kepribadian manusia. Pengaruh utama tiga dimensi manusia yang meliputi organo biologi, psiko edukasi dan sosio kultural, dalam kajian psikologi dimensi rohani sama sekali tidak masuk hitungan, karena dianggap termasuk dimensi kejiwaan dan merupakan penghayatan subyektif semata-mata (Bastaman, 2005: 49). Selain itu, psikologi apapun alirannya menunjukkan bahwa filsafat manusia yang mendasarinya bercorak anthroposentrisme yang menempatkan manusia sebagai pusat dari segala pengalaman dan relasi-relasinya serta penentu utama semua peristiwa yang menyangkut masalah manusia dan kemanusiaan. Pandangan ini mengangkat derajat manusia ke tempat teramat tinggi. Pada konteks ini manusia seakan prima causa yang unik, pemilik akal budi yang sangat hebat, serta memiliki kebebasan penuh untuk berbuat apa yang dianggap baik dan sesuai baginya.

Berangkat dari pemahaman tentang potensi manusia dan relasi sosialnya, perlu dipahami aspek kejiwaan manusia dalam kehidupan sosial dengan perangkat psikologi sosial. Dalam upaya memahami lebih dalam psikologi sosial secara komprehensif, maka perlu dikemukakan beberapa pengertian psikologi sosial. Psikologi sosial adalah cabang psikologi yang berupaya untuk memahami dan menjelaskan berpikir, berperasaan, dan berperilaku individu yang dipengaruhi oleh kehadiran orang lain. Kehadiran orang lain itu dapat dirasakan secara langsung, diimajinasikan, ataupun diimplikasikan (Hanurawan, 2010: 1). Kehadiran orang lain dalam konteks sosial bisa berbentuk kelas 
pembelajaran, karena dalam kelas terjadi interaksi efektif antara peserta didik dengan guru atau antar peserta didik. Intensitas dan lamanya waktu interaksi dapat memberikan pengaruh pada tingkah laku setiap individu yang terlibat.

Psikologi sosial menguraikan dan menerangkan kegiatan-kegiatan manusia, dan khususnya kegiatan-kegiatannya di dalam hubungan dengan situasi-situasi sosial. Dan situasi sosial itu adalah situasi di mana terdapat interaksi (hubungan timbal-balik) antarorang ataupun orang dan hasil kebudayaan orang (Gerungan, 1987: 28-29). Psikologi sosial sebagai salah satu cabang psikologi yang paling penting memiliki beberapa tujuan keilmuan, yaitu untuk memahami, menjelaskan, meramalkan, memodifikasi, dan memecahkan masalah terkait dengan cara berpikir, berperasaan, dan berperilaku individu yang dipengaruhi oleh kehadiran orang lain. Gejala-gejala psikologis sosial sebagai obyek yang dipelajari dalam psikologi sosial antara lain adalah: persepsi sosial, perilaku mencintai, perilaku individu dalam seting organisasi, persuasi, hubungan sikap dan perilaku, perilaku individu dalam kelompok, perilaku agresi, perilaku komunikasi, hubungan interpersonal, dan perilaku membantu orang lain (perilaku prososial). Dengan penjelasan tersebut dapat dipahami bahwa perilaku seseorang salah satu faktor pembentuknya adalah komunitas yang dimiliki, sehingga pemilihan lingkungan pergaulan menjadi sesuatu yang penting sebagai media pembelajaran.

Ada tiga wilayah studi psikologi sosial, antara lain: Pertama, studi tentang pengaruh sosial terhadap proses individual, misalnya studi tentang persepsi, motivasi, proses belajar, atribusi (sifat). Kedua, studi tentang proses-proses individual bersama, seperti bahasa, sikap sosial dan sebagainya. Ketiga, studi tentang interaksi kelompok, misalnya kepemimpinan, komunikasi, hubungan kekuasaan, otoriter, konformitas (keselarasan), kerja sama, persaingan, peran dan sebagainya (Sarwono1995: 3). Perbedaan antara psikologi sosial dengan sosiologi adalah dengan melakukan tinjauan terhadap masalah-masalah sosial, Psikologi sosial lebih menekankan tingkat unit analisis perilaku individual dalam menghadapi stimulus-stimulus sosial.Sedangkan sosiologi lebih menekankan pada hubungan timbal balik individu dan masyarakatnya dengan titik berat pada interaksi sosial. Hal ini berarti psikologi sosial lebih menekankan level analisis yang bersifat mikro, sedangkan sosiologi lebih menekankan level analisis yang bersifat makro (Hanurawan, 2010: 2). Kelas pembelajaran yang terdiri beberapa peserta didik dan guru yang saling berinteraksi secara intens, tentu dapat memberi pengaruh terhadap pembentukan perilaku sosial anggotanya. 
Psikologi sosial merupakan studi ilmiah (scientific study), perilaku individu (individual behavior), perilaku sosial (social behavior), dan stimulus sosial (social stimulus)/interaksi sosial (social interaction) (Walgito, 2011: 2). Minat utama psikologi sosial adalah mencari pemahaman tentang sebab-sebab atau faktor-faktor yang membentuk perilaku, pikiran atau perasaan individu dalam latar atau setting sosial (Dayakisni dkk., 2012: 6). Dalam proses pembelajaran, kelas merupakan social design yang disusun bersama antara peserta didik dan guru untuk melakukan rekayasa perilaku sesuai tujuan yang akan dicapai.

Psikologi sosial sebagai ilmu yang mempelajari perilaku manusia dengan pendekatan lintas budaya sebagai cara pandang mengenai pemahaman kebenaran dan prinsip-prinsip perilaku manusia dalam sebuah kerangka lintas budaya. Di mana budaya sebagai seperangkat sikap, nilai, keyakinan dan perilaku yang dimiliki oleh sekelompok orang, namun demikian ada derajat perbedaan pada setiap individu, dan dikomunikasikan dari satu generasi ke generasi berikutnya. Matsumoto mengatakan:

"Culture as a set of attidues, values, beliefs, and behaviors shared by a group of people, but different for each individual, communicated from one generation to the next" (Dayakisni dkk., 2008: 5).

Budaya sebagai seperangkat sikap, nilai-nilai, keyakinan, dan perilakubersama oleh sekelompok orang, tetapi berbeda untuk setiap individu, dikomunikasikan dari satu generasi ke generasi berikutnya. Budaya sebagai suatu kebiasaan yang berkembang dalam masyarakat, termasuk nilai-nilai, kepercayaan-kepercayaan dan perilaku suatu kelompok masyarakat, tetapi perbedaan di antara masingmasing individu serta komunikasi antara generasi terus berlanjut hingga masa yang akan datang. Perilaku sosial bisa dibentuk dari pembiasaan yang direncanakan oleh pelaku atau pemiliknya. Dalam konteks pembelajaran atau pendidikan budaya sekolah maupun budaya kelas merupakan sesuatu yang penting bagi terbentuknya perilaku yang diinginkan bersama. Oleh karena itu sangat penting peran pemangku kepentingan pendidikan atau sekolah dalam membentuk perilaku peserta didik.

Usaha untuk mengintegrasikan psikologi dan Islam yaitu psikologi dipakai sebagai pisau analisis masalah-masalah umat Islam dan Islam dipakai sebagai pisau analisis untuk menilai konsep-konsep psikologi. Usaha tersebut mempunyai keunggulan dan kelemahan. Usaha pertama mempunyai keunggulan, yaitu memanfaatkan psikologi untuk memberikan penjelasan problem umat Islam serta meningkatkan sumber daya umat Islam. Sedangkan kekurangannya adalah konsep-konsep psikologi mempunyai keterbatasan dan 
bahkan kemungkinan bias yang sangat besar, karena seringkali mereduksi Islam ke dalam pengertian-pengertian yang parsial dan tidak utuh (Ancok dkk., 2008: 3). Cara kedua mempunyai keunggulan mencoba melakukan kajian kritis terhadap psikologi, sehingga tahu kelemahan dan kekuatan konsep psikologi. Sementara kelemahannya adalah titik berangkat pembahasannya adalah konsep psikologi, sehingga sering terjebak, yaitu memandang persoalan berangkat dari pemahaman terhadap konsep psikologinya ketimbang Islamnya. Cara pandang yang ketiga, mencoba membangun konsep psikologi baru yang berdasarkan pada Islam, sehingga menghasilkan pemahaman dan pengertian tentang Psikologi Islam.

Islam adalah agama fitrah, sehingga pokok-pokok isi ajarannya sesuai dengan fitrah manusia. Fitrah adalah potensi dasar yang menyebabkan manusia hidup, tumbuh dan berkembang, mempunyai kemampuan untuk mengatur perikehidupannya, berbudaya dan sistem kehidupan masyarakat. Sebagai agama fitrah, pokok-pokok ajaran Islam akan tumbuh dan berkembang sesuai dengan fitrah kemanusiaan (Nasr, 1988: 11). Karena itu, pokok ajaran Islam telah mampu untuk beradaptasi dan berintegrasi yang sistem hidup dan budaya yang dimasukinya. Manusia secara fitrah akan dituntun menuju kebenaran Islam yang akan membawa kepada kebahagian hidup. Dengan mengikuti perkembangan zaman, studi Islam akan mempunyai tantangan baru, yaitu bagaimana Islam mampu membawa umat Islam keluar dari belenggu ketertinggalan zaman, agar jargon Islam sebagai agama yang universal, 'alIslam shalih likuli zaman wa al-makan' menjadi kenyataan. Nilai-nilai ajaran Islam akomodatif terhadap perkembangan zaman kapan pun dan di mana pun.

Psikologi Islami adalah sistem disiplin ilmu perihal manusia yang meliputi wawasan tentang manusia, teori-teori yang dibangun atas sumber-sumber formal Islam dan semangat Islam, metodologi, serta pendekatan aplikatif atas masalah-masalah (Ancok dkk., 2008: 164). Islam adalah agama bagi seluruh manusia, dan bukan hanya untuk kaum muslim saja. Pemikiran itu yang melandasi umat Islam melakukan rekontruksi Islami dalam kajian psikologi ini merupakan salah satu proyek kemanusiaan. Psikologi adalah milik semua umat manusia. Siapa pun dapat memberikan kontribusi, merekonstruksi arahnya, mengembangkan konsepnya serta memperkaya kajiannya.

Kaum muslim telah berhasil menerapkan konsep ilmiah dalam keilmuan tanpa harus membatasinya dengan suatu ideologi. Namun, Eropa telah menerapkan konsep yang sama dan mengubahnya menjadi satu ideologi dalam memahami alam semesta, kehidupan, dan manusia. Dengan kajian psikologi 
Islami, maka akan terjadi penyatuan antara ilmu pengetahuan yang didapatkan melalui pemikiran (akal) dengan ilmu pengetahuan yang didapatkan melalui wahyu, setelah sebelumnya dicerai-beraikan. Apabila selama ini pembahasan pendayagunaan psikologi Islami untuk mengembangan psikologi "barat", maka, mengapa tidak mendayagunakan psikologi "barat" untuk mengembangkan psikologi Islami? (Taufiq, 2006: 59-60).

Pada saat kajian tentang jiwa dibahas pada ilmu kalam (Filsafat), Ilmu Fiqih, Ilmu Tasawuf, maka label tersebut tidak dibutuhkan karena konsep yang ada dalam ilmu-ilmu Islam tersebut sudah jelas. Dr. Fua'd Abu Hatab menyebutkan bahwa orang pertama yang menggunakan kata "Psikologi Islami” adalah Dr. Ahmad Fu'ad Ahwany (1963). Pemahaman tentang penggunaan penamaan Psikologi islami mempunyai pengertian satu bentuk psikologi yang mendasarkan diri pada pandangan dunia (world view) Islam, dimana diasosiasikan dengan Islam sebagai landasan dasar dan orientasi dari psikologi. Istilah Islami dianggap cukup tepat dalam menggambarkan sebuah sifat keislaman yang luas sekaligus tidak berpretensi untuk menjadi ajaran yang absolut dan tidak berubah melainkan senantiasa bisa dikaji dan dilakukan ijtihad ulang jika diperlukan sesuai dengan dinamika yang terjadi pada dunia ilmu pada umumnya.

Psikologi Islam berarti psikologi islami memiliki beberapa karakeristik khusus yang membedakan dari corak atau aliran psikologi lainnya (Aryani, 2003: 152). Psikologi Islam adalah sebuah gagasan serta gerakan Islamisasi psikologi yang mempunyai landasan dan orientasi nilai-nilai keislaman. Sementara Baharuddin membuat formulasi paradigma Psikologi Islami berupaya mengatasi relasi paradigma humanistik yang menjunjung tinggi nilai-nilai dan kualitas kemanusiaan. Manusia dipandang sebagai subyek dalam relasi antara manusia dan alam. Manusia yang menentukan dan berkuasa atas dirinya sendiri. Manusia memiliki kebebasan penuh dan kebebasan itu identik dengan diri manusia. Paradigma humanistik memandang manusia sebagai makhluk subyektif, indeterministik, optimistik, dan humanistik. Psikologi Islam yang humanistik dan transpersonal keduanya menaruh perhatian pada kebebasan dan kualitas kemanusiaan berupa pikiran, perasaan dan kemauan.

Sedangkan paradigma psikologi islami mengatasi relasi paradigma humanistik dan transpersonal, namun pada saat yang sama Psikologi Islam berada di bawah paradigma 'spiritual theistik'. Dimana manusia bebas menentukan tingkah lakunya bersandarkan pikiran, perasaan dan kemauannya, namun pada saat yang bersamaan, manusia juga bertanggung jawab terhadap lingkungan 
alam, manusia dan Tuhannya. Tanggung jawab terhadap alam adalah untuk melestarikannya, tanggung jawab terhadap sesama manusia adalah untuk mensejahterakannya, dan tanggung jawab kepada Tuhan adalah untuk mencari ridha-Nya. Posisi demikian membuat manusia menjadi 'representatif-responstif dari relasi paradigma 'mekanistik-humanistik-theistik'.

Tingkah laku manusia merupakan proses representatif aktualisasi potensi batin dalam merespon stimulus lingkungannya, sehingga paradigma itu disebut paradigma fitrah. Dimana manusia senantiasa menampilkan dua sisi sekaligus, yaitu sisi asalnya (esensial) dan sisi keberadaannya (eksistensial). Fitrah sisi asalnya menampilkan sisi spiritual-transendental, sementara sisi keberadaannya menampilkan sisi empiris-historis manusia (Baharudidin, 2007: xiv-xv). Oleh karena itu Psikologi Sosial Islami adalah kajian ilmiah yang berusaha memahami keadaan dan sebab-sebab terjadinya perilaku individu dalam situasi sosial dengan menggunakan pandangan dunia Islam. Perbedaan Psikologi Sosial Islami dengan Psikologi Sosial kontemporer adalah bahwa dasar penyusunan dari Psikologi Sosial Islami adalah kitab suci (al Quran, hadits serta penafsiran atasnya), pemikiran spekulatif dan hasil penelitian empiris. Kitab suci sengaja diletakkan sebagai sumber utama kebenaran karena sumber utama ajaran Islam adalah al Quran. Pemikiran spekulatif dipergunakan karena ketika suatu pengetahuan dan gagasan itu ada di dalam pemikiran, maka ia bersifat relatif kebenarannya. Tingkat kebenarannya akan meningkat bila ia didukung oleh penelitian empiris. Dan hasil dari penelitian empiris didasarkan pada realitas yang diperoleh dengan berbagai metode ilmiah (bocahbancar. wordpress.com, 04/19/2011).

Berkaitan dengan potensi manusia sebagai makhluk sosial dan sekaligus sebagai spiritual yang mempunyai jiwa spiritual mampu berinteraksi dalam kehidupan sosial bersama dengan yang lain, menuntut peran sosial sesuai dengan potensinya. Peran tersebut bisa berjalan dengan baik apabila dilakukan transformasi nilai-nilai yang positif melalui media pembelajaran, agar bisa mencapai hasil yang maksimal media pembelajaran tersebut adalah pembelajaran pendidikan kewarganegaraan. Hal ini didasakan pada pemikiran, karena salah satu misi kegiatan pembelajarn PKn adalah menanamkan keterampilan sosial dan mengembangkan karakter positif sebagai warga Negara yang diawali pemahaman nilai moral dan norma menuju smart and good citizenship.

Beretika Islam dalam konteks Indonesia adalah smart dan good citizenship. Psikologi Islam beretika Islam dalam konteks kewarganegaraan adalah smart dan good citizanship. Multikulturalisme adalahkondisi riil masyarakat Indonesia 
yang menuntut masing-masing individu memahami hidup bersama dengan beretika menurut norma, nilai moral agama dan aturan negara. Inti etika kehidupan yang bersifat komplementer dan saling melengkapi.

Urgensi pendidikan multikulturalisme adalah alternatif pemecahan masalah (Mahfud, 2009: 207-216). Perbedaan sistem moral, nilai dan norma membutuhkan dialog, bukan penghancuran yang satu atas yang lain. Lembagalembaga pendidikan dan budaya dapat menjadi model dialog, dengan cara mendorong diskusi yang jujur dan terbuka. Masyarakat yang memperjuangkan kebebasan dan persamaan berdiri di atas perbedaan-perbedaan budaya. Janji moral multikulturalisme bergantung pada nilai-nilai saling mendengarkan dan saling menghargai. Pendidikan multikulturalisme merupakan pendidikan yang mengembangkan prinsip demokrasi dalam berkeadilan sosial (Nieto, 2002: 29). Prinsip demokrasi terimplementasi dalam model pembelajaran yang tidak hanya secara doktrinal dalam proses sampai pada hasil pembelajaran. Keadilan sosial dapat diterapkan pada peserta didik dengan memahami prinsip-prinsip keadilan dalam masyarakat dan contoh implementasinya dalam pembelajaran.Implementasi pendidikan multikultural yang diintegrasikan dengan mata pelajaran di sekolah merupakan bentuk pedagogi kritis dan reflektif yang menjadi basis aksi perubahan dalam masyarakat.

Pendekatan pendidikan multikultural dapat memecahkan persoalan konflik dan disharmonisasi dalam masyarakat. Di lain sisi, struktur budaya masyarakat Indonesia teramat beragam sehingga menjadi tantangan bagi dunia pendidikan untuk mengelola perbedaan itu menjadi sebuah kekuatan, dan bukannya sumber perpecahan (Mahfud, 2009: 209-215). Konflik yang timbul di masyarakat sering terjadi karena kurang mampu memahami perbedaan dan menjalankan sesuatu dalam keragaman. Bila pemahaman tentang perbedaan sebagai suatu realitas sudah baik, maka kearifan akan memberikan nilai tambah dalam pergaulan sesamanya. Masyarakat mampu menempatkan diri dalam setiap kondisi yang terjadi.

Dalam konteks SMP Al Islam 1 Surakarta peserta didik dapat mengembangkan sikap, mental dan perilaku yang sesuai dengan nilai-nilai pembelajaran, mampu menerima perbedaan sekalipun di tengah keragaman yang ada. Jiwa kebersamaan tercermin dalam pembelajaran PKn. Bahkan peserta didik bisa merasakan kehadiran orang lain dengan aneka perbedaan dapat diterima dengan baik, termasuk adanya kelas inklusi dengan peserta didik yang mempunyai kebutuhan khusus, peserta didik bisa membaur dalam hubungan sosialnya (Wawancara Rohmat Abdullah, 20 Februari 2014). 


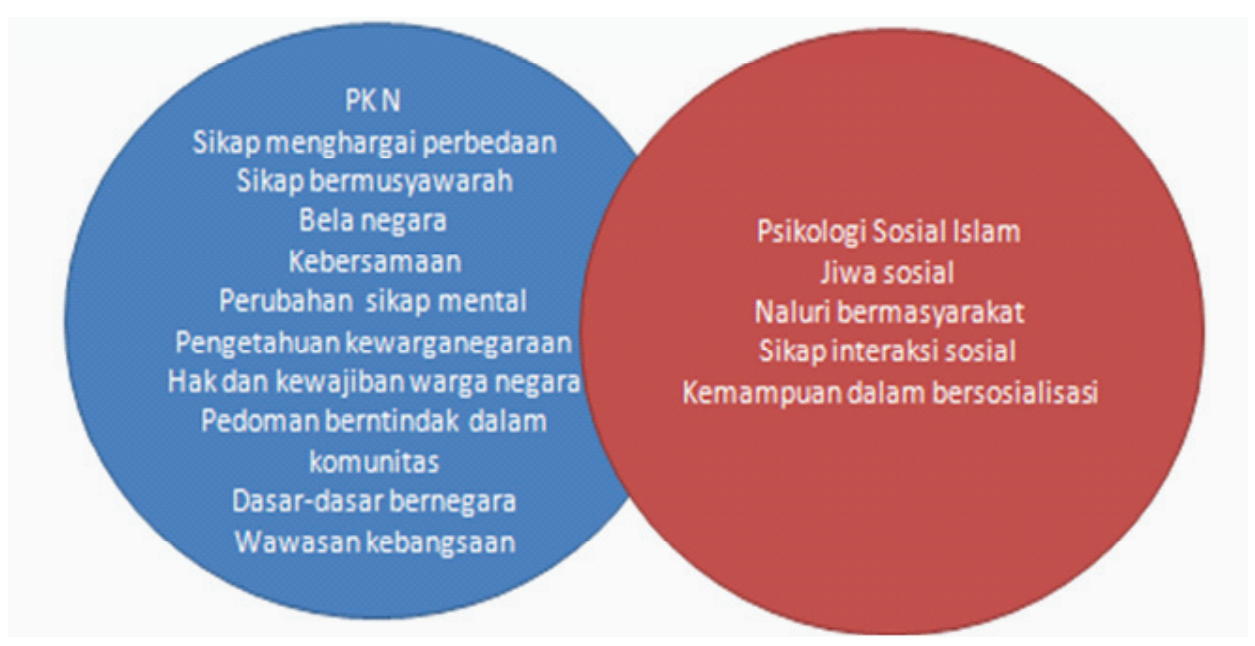

Gambar 1. PKN dan Psikologi Sosial Islam (data diolah)

Hubungan Pembelajaran PKn mengajarkan sikap menghargai perbedaan, sikap bermusyawarah, bela negara, perubahan sikap mental, pengetahuan kewarganegaraan, mengetahui hak dan kewajiban warga negara yang baik, pedoman bertindak dalam komunitas, dasar-dasar kehidupan berbangsa dan bernegara, wawasan kebangsaan.

Psikologi Sosial Islam mengembangkan jiwa sosial, naluri manusia yang selalu bermasyarakat, berbangsa dan bersuku-suku, sikap berinteraksi, kemampuan bersosialisasi, mengakui keragaman, mengakui keberagamaan, mengakui kebersamaan. Relasi keduanya sama-sama mengakui adanya keberagaman, kebersamaan, dan toleransi.

\section{Relasi Psikologi Sosial Islam dengan Multikulturalisme}

Kemampuan hidup berdampingan dengan orang lain yang berkeyakinan berbeda, mengakui perbedaan. Mampu menerima dalam perbedaan, mengakui keberadaan yang lain dalam perbedaan. Pluralisme, multikultural saling mengakui perbedaan dan menerima perbedaan. Kemampuan hidup bersama dan berdampingan dengan yang lain merupakan kebutuhan sekaligus sebagai suatu keterampilan dan kecakapan hidup. Kemampuan mengakui adanya perbedaan, akan membawa dampak kepada upaya untuk menghargai realitas yang berbeda dengan dirinya.

Masyarakat adalah gabungan dari kelompok individu yang terbentuk berdasarkan tatanan sosial tertentu. Dalam kepustakaan ilmu-ilmu sosial dikenal 
tiga bentuk masyarakat, yaitu: masyarakat homogen; masyarakat majemuk dan masyarakat heterogen. Masyarakat homogen bercirikan anggotanya tergolong dalam satu asal atau suku bangsa dengan satu kebudayaan yang digunakan sebagai pedoman hidup sehari-hari. Masyarakat majemuk terdiri atas sejumlah suku bangsa yang merupakan bagian dari bangsa itu.

Masyarakat heterogen memiliki ciri pranata-pranata primer yang bersumber pada kebudayaan suku bangsa yang telah diseragamkan oleh pemerintah nasional, kekuatan politik suku bangsa telah dilemahkan oleh sistem nasional melalui pengorganisasian yang berdasarkan solidaritas, memiliki pranata alternatif yang berfungsi sebagai upaya untuk mengakomodasi perbedaan dan keragaman, dan adanya tingkat kemajuan yang tinggi dalam kehidupan ekonomi dan teknologi sebagai akibat dari perkembangan pranata-pranata alternatif yang beragam (Arifin, 2006: 146).

Kemampuan menciptakan ukhuwah Islamiyah dalam arti luas, yakni persaudaraan yang bersifat Islami, bukan sekedar persaudaraan antar umat Islam sebagaimana yang selama ini dipahami, tetapi juga mampu membangun persaudaraan antar sesama. Menurut Islam, semua agama harus dilindungi, dan para pemeluknya harus diberi kebebasan untuk melaksanakan agamanya. Hanya saja konsep kebebasan beragama ini lebih mencerminkan pandangan hidup, perilaku dan mentalitas "having a religion". Perlu dikembangkan dialog antar umat beragama yang lebih mencerminkan sikap, perilaku dan mentalitas "being religious" (Maksum, 2011: xvi). Oleh karena itu multikultural bukanlah doktrin politik pragmatik melainkan sebagai cara pandang kehidupan manusia.

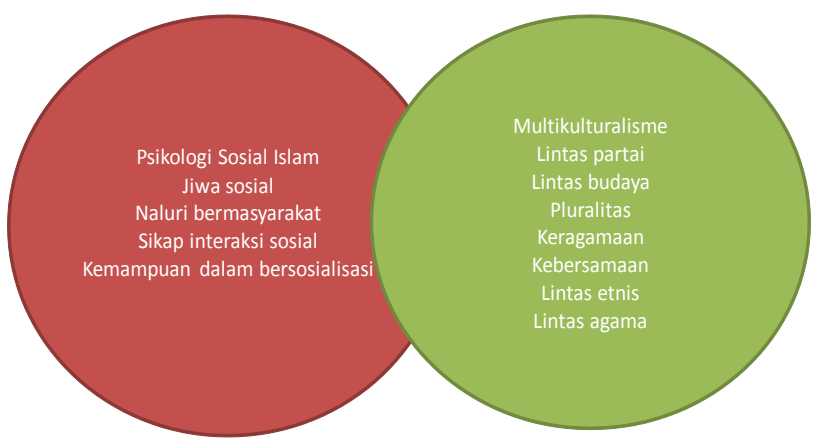

Gambar 2. Relasi Psikologi Sosial Islam dan Multikulturalisme (data diolah)

Psikologi Sosial Islam mengembangkan jiwa sosial, naluri manusia yang selalu bermasyarakat, berbangsa dan bersuku-suku, sikap berinteraksi, 
kemampuan bersosialisasi, mengakui keragaman, mengakui keberagamaan, mengakui kebersamaan.Multikulturalisme mengakui adanya lintas partai, lintas budaya, lintas etnis, lintas agama, pluralitas, keragaman, keberagamaan, kebersamaan.

\section{Relasi PKn dengan Multikulturalisme}

Pendidikan Kewarganegaraan membekali peserta didik kemampuan untuk memahami secara kognitif adanya realitas perbedaan, dan mampu mengaplikasikan di tengah keragaman yang ada. Guru mempunyai dua tanggung jawab dalam implementasi pembelajaran pendidikan multikulturalisme di sekolah SMP Al Islam 1 Surakarta, yakni: (1) menyiapkan peserta didik untuk menghadapi arus budaya modernisasi dan globalisasi; (2) membangun pemikiran peserta didik untuk mempertahankan kemajemukan masyarakat, baik perspektif etnisitas, etnokultural, maupun etnoreligius mereka; dan (3) interaksi silang etnisitas, etnokultural, dan etnoreligius merupakan wahana mengasah identitas, serta mengandaikan diri mereka menyatu dalam suatu komunitas(Maksum, 2011: 230).

Pertemuan budaya lokal dan budaya nasional dengan arus budaya modernisasi dan globalisasi dapat menimbulkan ancaman serius bagi kehidupan masyarakat apabila pemikiran keberagaman generasi muda (peserta didik) belum mapan. Namun, pertemuan budaya lokal dan budaya nasional dengan budaya modernisasi dan globalisasi justru menjadi social cultural capital (Tilaar, 2004: 93-94). Karena mampu melakukan seleksi, bahkan digunakan untuk penguatan budaya nasional. Peserta didik penting untuk memahami keberagaman sosial-budaya mereka sendiri. Dengan demikian, ketika peserta didik berhadapan dengan budaya modernisasi dan budaya globalisasi, peserta didik tidak mudah tercerabut dari akar budaya sendiri.

Setiap pengalaman individu, khususnya pengalaman keagamaan merupakan pertemuan ranah konatif, yakni dialami secara langsung dan murni. Dalam pengalaman konatif itu terdapat pertemuan antara "aku" dan "yang lain”(Rachman, 2004: 4). Dalam bahasa lain bisa diungkapan bagimu agamamu dan bagiku agamaku. Dalam konteks ibadah keagamaan masingmasing orang yakin dan melaksanakan kepercayaannya demikian juga mengakui dan memahami perbedaannya. Namun dalam dimensi sosial masyarakat bisa bekerjasama. Pengalaman ini tidak dapat diartikan secara inderawi, seperti pengalaman empiris dalam pengetahuan sains, karena pengalaman mengacu pada pertemuan antara subjek dan objek, sehingga pengalaman dapat membawa 
dan membangun pada kebersamaan.

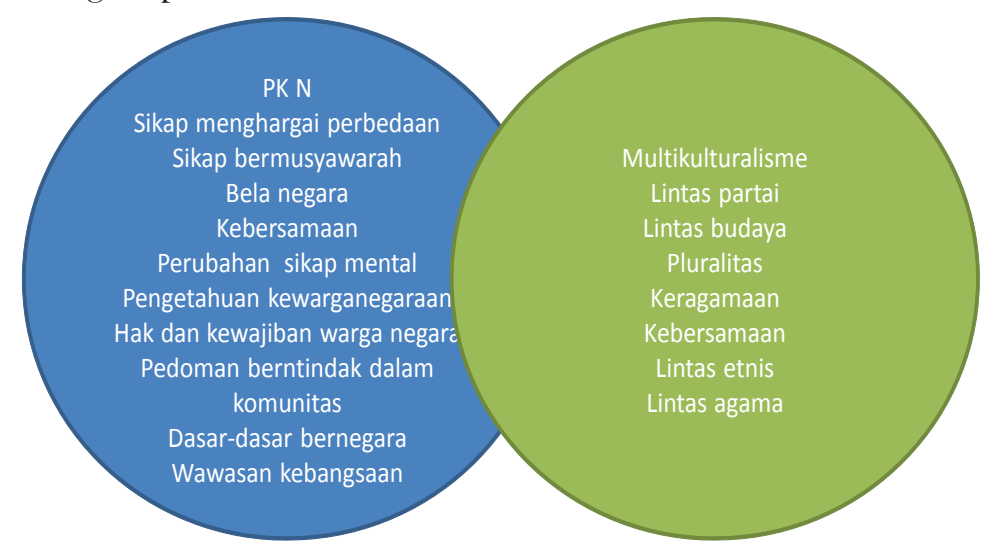

Gambar 3. Relasi PKn dan Multikulturalisme (data diolah)

Relasi PKn dan multikulturalisme melahirkan sikap menghargai perbedaan, sikap bermusyawarah, bela negara, kebersamaan, perubahan sikap dan mental, pengetahuan kewarganegaraan, hak dan kewajiban warga negara, pedoman bertindak dalam komunitas, dasar-dasar bernegara, wawasan kebangsaan. Multikulturalisme mengakui adanya lintas partai, lintas budaya, lintas etnis, lintas agama, pluralitas, keragaman, keberagamaan, kebersamaan.

\section{Relasi Psikologi Sosial Islam, PKn dan Multikulturalisme}

Relasi psikologi sosial Islam bertolak dari pemahasan di muka dapat ditarik kesimpulan hubungan antara psikologi sosial Islam bertujuan untuk mengambangkan studi tentang perkembangan jiwa manusia dalam perspektif Islam sehingga bisa hidup bersama dalam realitas kehidupan yang multikultural. Bahwa realitas keberagamaan tidak mengancam eksisten manusia dalam menjalin dan berinteraksi dengan yang lain yang bukan kelompoknya atau tidak sama dalam etnis, budaya, bahasa, suku, dan agama. Tetapi mereka masih bisa berinteraksi, bahkan dengan nilai-nilai dasar Islam bisa dikembangkan untuk hidup berdampingan dan saling menguntungkan satu sama lain.

Pemahaman terhadap multikultural dapat ditransformasikan melalui pembelajaran Pendidikan Kewarganegaraan secara simultan dan terus menerus ditanamkan kepada peserta didik, sehingga mempunyai karakter yang responsif terhadap realitas yang ada. Pluralitas bukan halangan untuk mengembangkan diri dalam kelompok yang berbeda, sebaliknya dalam keragaman mereka bisa berbagi dan bertukar manfaat yang lebih besar. 


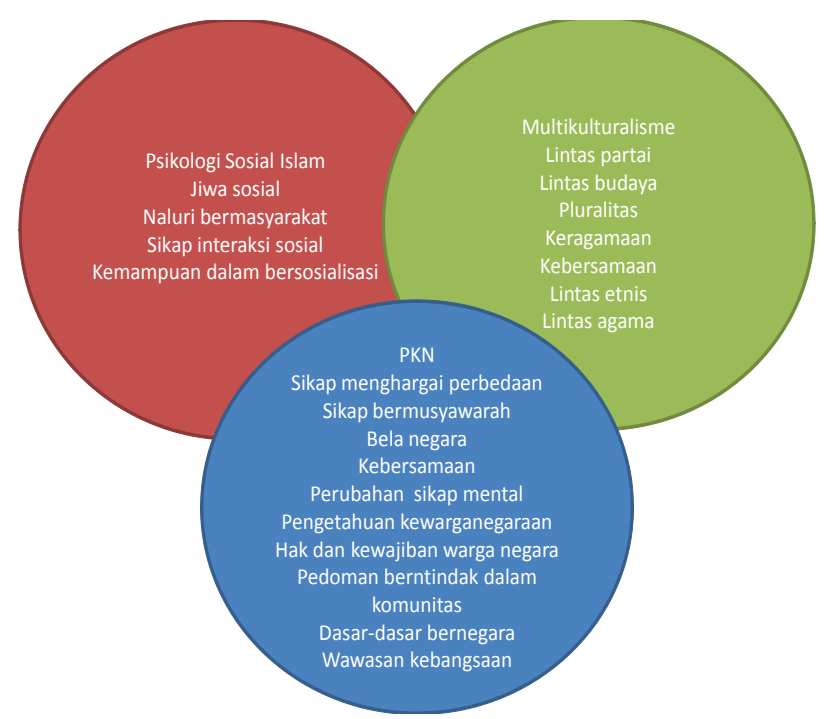

Gambar 4. Relasi Psikologi Sosial Islam, PKn, Multikulturalisme (data diolah)

Psikologi Sosial Islam merupakan bagian psikologi sosial mempelajari tingkah laku manusia, mempelajari hubungan manusia dengan yang lainnya dari aspek kejiwaannya, jiwa manusia yang selalu berhubungan dengan orang lain, kemampuan manusia beradaptasi dengan lingkungan yang beragam, kemampuan manusia menghargai perbedaan yang ada, kemampuan manusia untuk hidup dalam lingkungan yang berbeda.

PKn pembelajaran yang membuat manusia menjadi pribadi yang smart dan good citizenship, pembelajaran kebangsaan, bela negara, toleransi, kebersamaan, kerukunan, secara implementasi sebagai berikut: civic knowledge yaitu kecakapan dan kemampuan penguasaan pengetahuan kewargaan yang terkait dengan materi pendidikan kewargaan (civic education) antara lain demokrasi, hak asasi manusia dan masyarakat madani (civil society), civic dispositions yaitu kecakapan dan kemampuan sikap kewargaan (civic dispositions) antara lain pengakuan kesetaraan, toleransi, kebersamaan, pengakuan keragaman, kepekaan terhadap masalah warga Negara antara lain masalah demokrasi dan hak asasi manusia, civic skills yaitu kecakapan dan kemampuan mengartikulasikan keterampilan kewargaan (civic skills) seperti kemampuan berpartisipasi dalam proses pembuatan kebijakan publik, kemampuan melakukan kontrol sosial terhadap penyelenggaraan negara dan pemerintahan. Dimana standar kompetensi kelulusan pada satuan pendidikan menengah umum bertujuan untuk meningkatkan keceradasan, pengetahuan, kepribadian, akhlak mulia, 
serta keterampilan untuk hidup mandiri dan mengikuti pendidikan lebih lanjut. Sebagaimana pasal 26 (2) Peraturan Pemerintah Nomor 19 Tahun 2005 tentang Standar Nasional Pendidikan.

Multikulturalisme merupakan pandangan dunia (worldview) yang kemudian dapat diterjemahkan dalam berbagai kebijakan kebudayaan yang menekankan tentang penerimaan terhadap realitas keragamaan, pluralitas dan multikultural yang terdapat dalam kehidupan masyarakat. Dengan menempatkan multikulturalisme sebagai pandangan dunia maka akan mudah untuk diimplementasikan dalam kesadaran politik. Menurut Bikhu Perehk, masyarakat multikultural merupakan suatu masyarakat yang terdiri dari beberapa macam komunitas budaya dengan segala kelebihannya, dengan sedikit perbedaan konsepsi mengenai dunia, suatu sistem arti, nilai, bentuk organisasi sosial, sejarah, adat serta kebiasaan (Parekh, 1997: 63). Sebab dengan pendidikan akan terbangun kesadaran akan multikulturalisme secara lebih mendasar.

Hubungan Psikologi Sosial Islam, PKn dan Multikulturalisme akan membentuk sosok warga negara yang mempunyai karakter sosial dan nasionalisme yang unggul yang mampu hidup dalam berbagai keragaman, tanpa kehilangan jati diri bangsa dan kepribadian Islami. Sehingga sifat-sifat dan karakter kepribadian menjadi unggul dan mulia. Pribadi yang mampu membawakan diri dalam posisi yang berbeda untuk berlaku tidak diskrimintaif dan menganggap sebagai sesuatu yang tidak berati, tetapi karakter keutamaannya terlihat dalam kiprah dan kepedulian terhadap yang lain. Mampu bersinergi dengan berbagai komunitas yang beragam, namun tetapi memegang prinsip untuk menjaga kesatuan dan persatuan. Perbedaan bukan menjadi halangan untuk bekerja sama mencapai tatanan kehidupan sosial yang harmonis dan penuh dengan tanggung jawab sosial memajukan lingkungan dan bangsa secara luas.

Berdasarkan wawancara dengan siswa SMP Al Islam 1 Surakarta menyatakan bahwa hasil pembelajaran PKn mengetahui hal-hal yang berkaitan dengan kewarganegaraan, berkembangnya jiwa sosial, perubahan sikap mental peserta didik dalam kehidupan sehari-hari, mengetahui aturan dalam kehidupan sosial, membangun kesadaran untuk taat pada aturan. Peserta didik mampu menerima perbedaan pengamalan agama antara khilafiyah satu dengan yang lain. Adapun hambatan yang dihadapi peserta didik dalam pembelajaran PKn masih kurangnya waktu untuk mempelajari dan mendalami materi. Dampak psikologis setelah belajar PKn siswa sangat menghargai keberadaan orang lain, hal tersebut ditunjukkan dalam diskusi 
kelas, ketika ada perbedaan dalam pendapat, mereka tetap mengakui adanya perbedaan, mengakui adanya perbedaan dengan yang lain, tetapi bisa hidup dalam kerukunan, mampu bekerjasama dengan kelompok lain yang lebih luas (Wawancara Saila, 8 Februari 2014).

Di luar kelas setelah kembali ke rumah dan berbaur dengan masyarakat lain menurut pengakuan Saila mereka bisa bergaul dengan teman-temanya yang sebaya sekalipun berbeda keyakinan agamanya. Setelah belajar PKn siswa merasa lebih percaya diri dalam pergaulan dengan lingkungannya yang berbeda atau dalam keragaman budaya setempat. Hal ini menunjukkan bahwa dinamika sosial peserta didik baik di dalam maupun di luar kelas, sudah dilandasi atau diwarnai oleh nilai-nilai multikulturalisme.

\section{Simpulan}

Pertama, PKn dengan psikologi sosial Islam. Pembelajaran PKn mengajarkan sikap menghargai perbedaan, sikap bermusyawarah, bela negara, perubahan sikap mental, pengetahuan kewarganegaraan, mengetahui hak dan kewajiban warga negara yang baik, pedoman bertindak dalam komunitas, dasar-dasar kehidupan berbangsa dan bernegara, wawasan kebangsaan.Psikologi Sosial Islam mengembangkan jiwa sosial, naluri manusia yang selalu bermasyarakat, berbangsa dan bersuku-suku, sikap berinteraksi, kemampuan bersosialisasi, mengakui keragaman, mengakui keberagamaan, mengakui kebersamaan. Relasi keduanya sama-sama mengakui adanya keberagaman, kebersamaan, dan toleransi.

Kedua, relasi PKn dan multikulturalisme melahirkan sikap menghargai perbedaan, sikap bermusyawarah, bela negara, kebersamaan, perubahan sikap dan mental, pengetahuan kewarganegaraan, hak dan kewajiban warga negara, pedoman bertindak dalam komunitas, dasar-dasar bernegara, wawasan kebangsaan. Multikulturalisme mengakui adanya lintas partai, lintas budaya, lintas etnis, lintas agama, pluralitas, keragaman, keberagamaan, kebersamaan.

Ketiga, psikologi sosial Islam dengan multikulturalisme. Psikologi Sosial Islam mengembangkan jiwa sosial, naluri manusia yang selalu bermasyarakat, berbangsa dan bersuku-suku, sikap berinteraksi, kemampuan bersosialisasi, mengakui keragaman, mengakui keberagamaan, mengakui kebersamaan. Multikulturalisme mengakui adanya lintas partai, lintas budaya, lintas etnis, lintas agama, pluralitas, keragaman, keberagamaan, kebersamaan.

Keempat, hubungan psikologi sosial Islam, PKn dan multikulturalisme akan membentuk sosok warga negara yang mempunyai karakter sosial dan 
nasionalisme yang unggul yang mampu hidup dalam berbagai keragaman, tanpa kehilangan jati diri bangsa dan kepribadian Islami. Sehingga sifatsifat dan karakter kepribadian menjadi unggul dan mulia. Pribadi yang mampu membawakan diri dalam posisi yang berbeda untuk berlaku tidak diskrimintaif dan mengganggap sebagai sesuatu yang tidak berati, tetapi karakter keutamaannya terlihat dalam kiprah dan kepedulian terhadap yang lain. Mampu bersinergi dengan berbagai komunitas yang beragam, namun tetapi memegang prinsip untuk menjaga kesatuan dan persatuan. Perbedaan bukan menjadi halangan untuk bekerja sama mencapai tatanan kehidupan sosial yang harmonis dan penuh dengan tanggung jawab sosial memajukan lingkungan dan bangsa secara luas.

\section{Daftar Pustaka}

Ancok, Djamaludin; Suroso, Fuat Nashori. 2008. Psikologi Islam Solusi Islam atas Problem-Problem Psikologi. Yogyakarta: Pustaka Pelajar.

Arifin, Bambang Syamsul. 2006. Psikologi Agama. Bandung: Pustaka Setia.

Aryani, Sekar Ayu. 2003. Psikologi Islami dan Psikologi Pastoral (Telaah Metodologi dalam Skema Teoritis Psiko-Religius [disertasi]. Program Pascasarjana IAIN Sunan Kalijaga Yogyakarta.

Baharudidin, 2007. Paradigma Psikologi Islami Studi Tentang Elemen Psikologi Al Quran. Yogyakarta: Pustaka Pelajar.

Bastaman, Hanna Djumhana. 2005. Integrasi Psikologi dengan Islam Menuju Psikologi Islami. Yogyakarta: Pustaka Pelajar.

Bocahbancar.wordpress.com/2011/04/09/psikologi-sosial-Islami-pemaafandan-kelapangdadaan/. Diakses, 3/12/2013.

Dayakisni, Tri; Hudaniah. 2012. Psikologi Sosial. Malang: UMM Press.

Dayakisni, Tri; Yuniardi, Salis. 2008. Psikologi Lintas Budaya. Malang: Penerbit Universitas Muhammadiyah Malang.

Gerungan, W. A. 1987. Psikologi Sosial. Bandung: Eresco.

Hanurawan, Fatta. 2010. Psikologi Sosial Suatu Pengantar. Bandung: Remaja Rosdakarya.

Mahfud, Choirul. 2009. Pendidikan Multikultural. Yogyakarta: Pustaka Pelajar. 
Maksum, Ali. 2011. Pluralisme dan Multikulturalisme Paradigma Baru Pendidikan Agama Islam di Indonesia. Yogyakarta: Aditya Media Publishing.

Muhaimin. 2011. Urgensi Pendidikan Islam Multikultural untuk Menciptakan Tolrenasi dan Perdamaian di Indonesia dalam Ali Maksum. Pluralisme dan Multikulturalisme Paradigma Baru Pendidikan Agama Islam di Indonesia. Yogyakarta: Aditya Media Publishing.

Nasr, Sayyed Hossein. 1988. Tradition Muslim in the Modern World. Kuala Lumpur: Foundation For Traditional Studies.

Nieto, Sonia. 2002. Language, Culture and Teaching. New Jersey: Lawrence Earlbaum.

Parekh, Bhikhu. 1997. National Culture and Multiculturalism dalam Kenneth Thomson (ed.),Media and Cultural Regulation. London: Sage Publications.

Rachman, Budhy Munawar. 2004. Islam Pluralis: Wacana Kesetaraan Kaum Beriman. Jakarta: Srigunting.

Sarwono, Sarlito Wirawan. 1995. Teori-teori Psikologi Sosial. Jakarta: RajaGrafindo Persada.

Taufiq, Muhammad Izzuddin. 2006. Panduan Lengkap dan Praktis Psikologi Islam. Jakarta: Gema Insani Press.

Tilaar, H.A.R.2004. Multikulturalisme: Tantangan-Tantangan Global Masa Depan dalam Transformasi Pendidikan Nasional. Jakarta: Grasindo.

Walgito, Bimo. 2011. Teori-Teori Psikologi Sosial. Yogyakarta: Andi.

Wawancara dengan Rohmat Abdullah, S. Pd. Pengelola Sekolah Inklusi SMP Al Islam 1 Surakarta. 20 Februari 2014.

Wawancara dengan Saila. Peserta Didik Kelas VIII SMP Al Islam 1 Surakarta. 8 Februari 2014.

Winataputra, Udin Saripudin. 2012. Pendidikan Kewarganegaraan Dalam Perspektif Pendidikan untuk Mencerdaskan Kehidupan Bangsa. Bandung: Widya Aksara Press.

Yaqin, M Ainul. 2005. Pendidikan Multikultural: Cross Cultural Understanding untuk Demokrasi dan Keadilan. Yogyakarta: Pilar Media. 